\title{
GEOPHYSICAL SURVEY FOR GROUNDWATER INVESTIGATION AROUND PARTS OF UNIVERSITY OF BENIN, NIGERIA
}

\author{
Osayamen Julius Imarhiagbe \\ Division of Earth Sciences and Geography \\ RWTH Aachen University, Aachen, Germany. \\ Isuan Airaoa Idonije \\ Department of Geology, University of Benin \\ Benin City, Edo State, Nigeria.
}

\author{
S. A. Salami \\ Department of Geology, University of Benin \\ Benin City, Edo State, Nigeria \\ Osayomore Moore Ogbegie \\ Department of Geology, University of Benin \\ Benin City, Edo State, Nigeria
}

\begin{abstract}
A geophysical survey of the University of Benin was carried out using the resistivity method for groundwater investigation. Five (5) vertical electrical sounding (VES) points were taken to ascertain the groundwater availability and depth to groundwater in the area. Areas recording low resistivities had a likelihood of being water bearing and so data collected was interpreted. The VES data indicated that between 5 to 7 layers of soil were encountered ranging from the topsoil to the aquiferous layer. The depths ranged between $106 \mathrm{ft}$ to 209ft. The flow direction and depth to water table models generated indicate a lower elevation around the central area and points located around this area would have a higher possibility of a high water yield.
\end{abstract}

\section{Keywords - Groundwater, Resistivity, Aquifer, Electrode}

\section{INTRODUCTION}

Groundwater has been described as the "water which exist below the surface of the earth" it is found within layers of sands and also saturates pore spaces in sedimentary and crystalline rocks. There is a continuous demand for water and the need for accessibility to portable water cannot be overemphasized.

Surface water cannot be dependable throughout the year, also, as a result of its high susceptibility to pollution and contamination, the need to look for other alternatives to portable water is very important. The world depends on groundwater as a source of quality fresh water. This is the water held in the subsurface within the zone of saturation under hydrostatic pressure below water table [1].

A geophysical field survey was carried out at different locations within the University of Benin, Ugbowo Campus, to investigate the groundwater availability in the area and also to ascertain the depth to water table in the Area. The method that was used was the Resistivity method of geophysical data acquisition. The aim of this study was to investigate groundwater availability in these areas and also the depth to groundwater using the vertical electrical sounding.

Degree of saturation have a direct influence on the resistivity of rocks. Water forms a conductive electrolyte in the presence of chemical salts in solution, in turn, the resistivity varies inversely with to the salinity [2]. The application of geophysics to a successful groundwater exploration in sedimentary terrains requires proper understanding of the hydro-geological characteristics and patterns of the area, study shows that geophysical methods are a reliable means of surveying subsurface structural and rock variation [3][4]

\section{THE STUDY AREA}

Benin city is underlain by sedimentary sequences that is part of the Niger Delta Basin [5]. The geology of the region is under a continuous and physicochemical transformation as sediments are still being deposited. The area is marked by top red tropical soils composed of low silica-sesquioxide ratio clay[6]. [7] classified these red clayey soils as of inorganic origin. The lithostratigraphy of the Benin Formation (Miocene- Recent) is characterized by $90 \%$ sand, conglomeratic gravels, clays, peat and lignite deposited in a continental coastal plain (fluvial) depositional setting [8][9]. Sands, sandstones and clays vary in colour from reddish brown to pinkish yellow on weathered surfaces to white in the deeper fresh surfaces. 


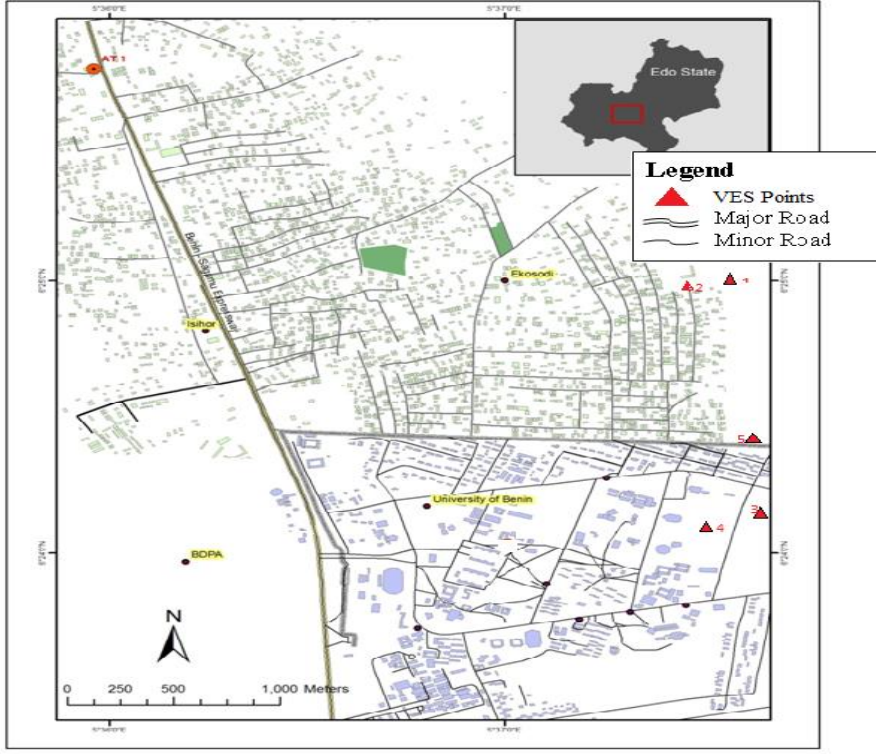

Figure 1: Map of Benin City showing the VES Locations (Modified after [7])

\section{METHODS}

The electrical resistivity method of geophysical survey measures both the lateral and vertical variations in the resistivity of the ground [10]. This is done by sending electrical current into the ground at the current electrodes and the corresponding potential difference is measured at the potential electrode.it is then converted to apparent resistivity value by multiplying with an appropriate geometrical factor. Different factors contribute to the resistivity in the subsurface [11]

Vertical Electrical Sounding of the study area was done using two electrode array methods - Wenner and Schlumberger Arrays. Stainless non-polarizing electrodes which were connected to an ABEM Terrameter SAS-1000 was used in the investigation. [12]

\subsection{Wenner Arrays}

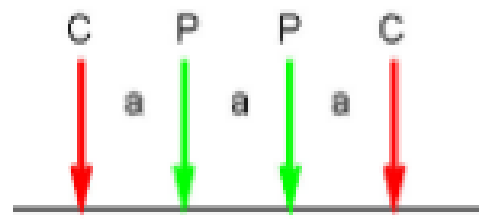

apparent resistivity $=\rho_{a}=2 \pi a\left(\frac{\Delta V}{I}\right)$

Figure 2: Wenner Array Configuration

During sounding, vary the a-spacing to get resistivity as a function of depth a-spacing is increased logarithmically, with 5-7 values per decade. The maximum value of a-spacing should be at least 3-5 times the maximum depth of investigation.
For profiling, Fix a-spacing and move whole array along a transect. The a-spacing should be approximately equal to the depth of investigation

3.2. Schlumberger Arrays

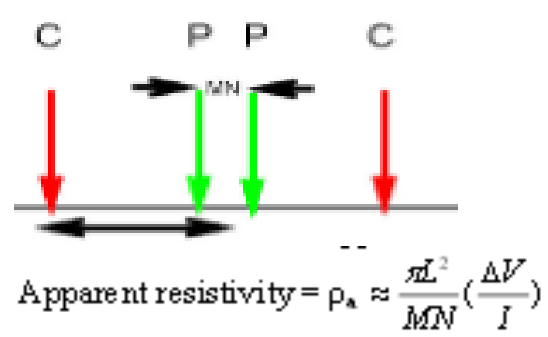

Figure 3: Schlumberger Array Configuration

This array keeps the potential electrodes $(\mathrm{P})$ stationary while the current electrodes (C) are moved out. The array is symmetric with current electrodes a distance $\mathrm{L}$ from the centre. The potential electrodes are separated by a distance MN.

As the current electrodes are moved out, $\Delta \mathrm{V}$ becomes smaller and ultimately becomes too small to measure. At this point, the current electrodes are moved out and measurements continue.

To account for the changing spacing of potential and current electrodes, a more complicated formula is needed for apparent resistivity. When apparent resistivity is plotted against half electrode spacing (L/2) in the Schlumberger configuration for various spacing, a smooth curve can be drawn through the points [13]

During sounding, vary the a-spacing to get resistivity as a function of depth, the a-spacing is increased logarithmically, with 5-7 values per decade. The maximum value of $L$ in a Schlumberger array should be at least 3-5 times the maximum depth of investigation.

\section{RESULTS}

The results collected from the field were used to generate a profile of the points of soundings. The software used was the IX1D software, which plotted the apparent resistivity against the spacing. The resistivity values generated the soil profile which gave information on the different soil types within the formation

Table 1: Interpretation Record of VES 1

\begin{tabular}{|l|l|l|l|l|}
\hline Layer & $\begin{array}{l}\text { Resistivity } \\
(\mathbf{\Omega m})\end{array}$ & $\begin{array}{l}\text { Thickness } \\
(\mathbf{m})\end{array}$ & Depth(m) & Lithology \\
\hline 1 & 842.66 & 0.68940 & 0.68940 & Topsoil \\
\hline 2 & 4579.1 & 1.8551 & 2.5445 & Sand (dry) \\
\hline 3 & 651.67 & 5.1352 & 7.6797 & Sand \\
\hline 4 & 9637.8 & 13.765 & 21.445 & Sand (dry) \\
\hline 5 & 1901.9 & 18.047 & 39.492 & Sand \\
\hline 6 & 509.26 & & & Sand (Aquiferous) \\
\hline
\end{tabular}


Published Online January 2020 in IJEAST (http://www.ijeast.com)
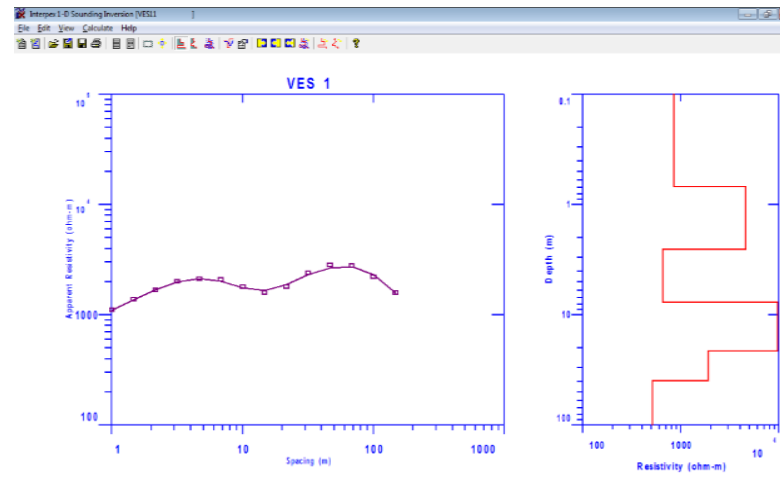

Figure 4: Geoelectric profile for VES 1

Table 2: Interpretation Record of VES 2

\begin{tabular}{|l|l|l|l|l|}
\hline Layer & $\begin{array}{l}\text { Resistivity } \\
(\mathbf{\Omega m})\end{array}$ & $\begin{array}{l}\text { Thickness } \\
(\mathbf{m})\end{array}$ & $\begin{array}{l}\text { Depth } \\
(\mathbf{m})\end{array}$ & Lithology \\
\hline 1 & 629.46 & 0.40663 & 0.40663 & Topsoil \\
\hline 2 & 4931.3 & 1.4087 & 1.8153 & Sand (dry) \\
\hline 3 & 983.57 & 3.5398 & 5.3551 & Sand \\
\hline 4 & 27897. & 13.235 & 18.590 & Sand (Very dry) \\
\hline 5 & 1061.4 & 45.218 & 63.808 & Sand (Aquiferous) \\
\hline 6 & 3162.5 & & & \\
\hline
\end{tabular}
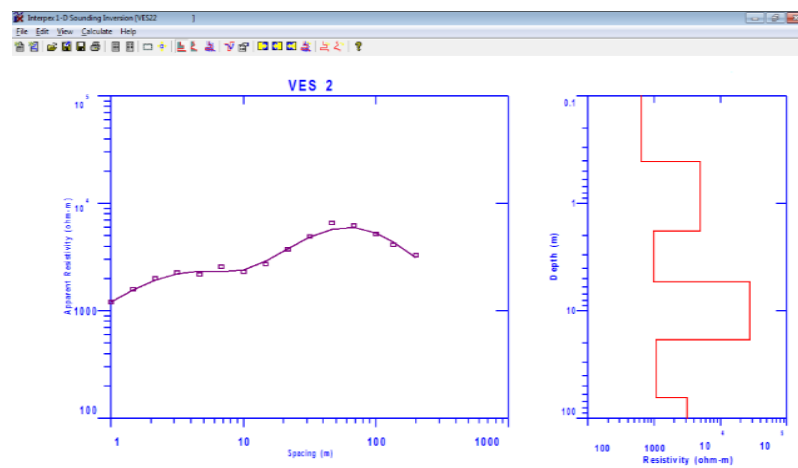

Figure 5: Geoelectric profile for VES 2

Table 3: Interpretation Record of VES 3

\begin{tabular}{|l|l|l|l|l|}
\hline Layer & $\begin{array}{l}\text { Resistivity } \\
(\mathbf{\Omega m})\end{array}$ & $\begin{array}{l}\text { Thickness } \\
(\mathbf{m})\end{array}$ & $\begin{array}{l}\text { Depth } \\
(\mathbf{m})\end{array}$ & Lithology \\
\hline 1 & 455.60 & 0.53050 & 0.53050 & Topsoil \\
\hline 2 & 541.34 & 1.5264 & 2.0569 & Sand \\
\hline 3 & 1505.7 & 4.6092 & 6.6661 & Sand (dry) \\
\hline 4 & 700.66 & 7.6853 & 14.351 & Sand \\
\hline 5 & 8092.2 & 23.237 & 37.588 & Sand (dry) \\
\hline 6 & 192.20 & & & $\begin{array}{l}\text { Sand } \\
\text { (Aquiferous) }\end{array}$ \\
\hline
\end{tabular}
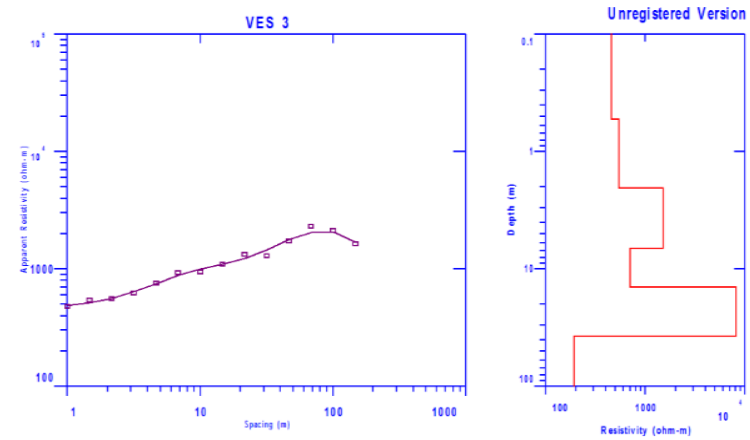

Figure 6: Geoelectric profile for VES 3

Table 4: Interpretation Record of VES 4

\begin{tabular}{|l|l|l|l|l|}
\hline Layer & $\begin{array}{l}\text { Resistivity } \\
(\mathbf{\Omega m})\end{array}$ & $\begin{array}{l}\text { Thickness } \\
(\mathbf{m})\end{array}$ & $\begin{array}{l}\text { Depth } \\
(\mathbf{m})\end{array}$ & Lithology \\
\hline 1 & 793.33 & 0.50235 & 0.50235 & Topsoil \\
\hline 2 & 840.33 & 0.96720 & 1.4695 & Sand \\
\hline 3 & 795.26 & 1.8362 & 3.3057 & Sand \\
\hline 4 & 739.16 & 1.5494 & 4.8551 & Sand \\
\hline 5 & 35228. & 8.7763 & 13.631 & Sand (very dry) \\
\hline 6 & 1056.7 & 18.782 & 32.413 & Sand (dry) \\
\hline 7 & 580 & & & Sand (Aquiferous \\
\hline
\end{tabular}

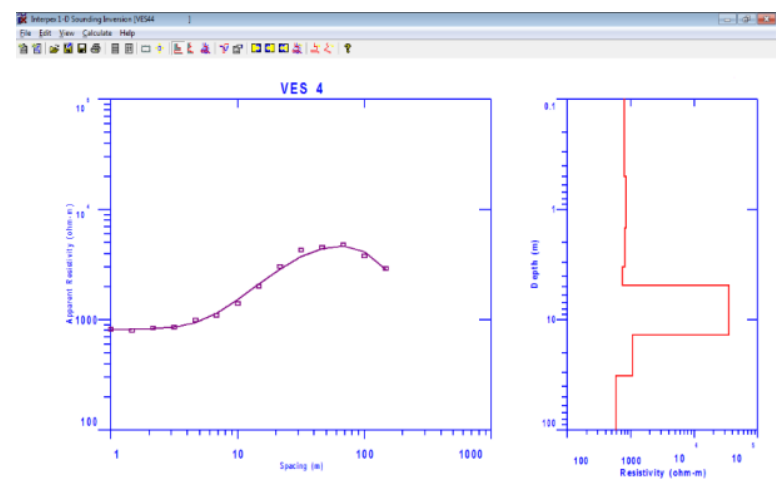

Figure 7: Geoelectric profile for VES 4

Table 5: Interpretation Record of VES 5

\begin{tabular}{|l|l|l|l|l|}
\hline Layer & $\begin{array}{l}\text { Resistivity } \\
(\mathbf{\Omega m})\end{array}$ & $\begin{array}{l}\text { Thickness } \\
(\mathbf{m})\end{array}$ & $\begin{array}{l}\text { Depth } \\
(\mathbf{m})\end{array}$ & Lithology \\
\hline 1 & 717.70 & 0.99170 & 0.99170 & Topsoil \\
\hline 2 & 256.42 & 1.4007 & 2.3924 & Sand \\
\hline 3 & 33721. & 7.5320 & 9.9244 & Sand (very dry) \\
\hline 4 & 3357.4 & 8.1878 & 18.112 & Sand (dry) \\
\hline 5 & 575.67 & 41.636 & 59.748 & Sand (Aquiferous) \\
\hline 6 & 1760.8 & & & \\
\hline
\end{tabular}



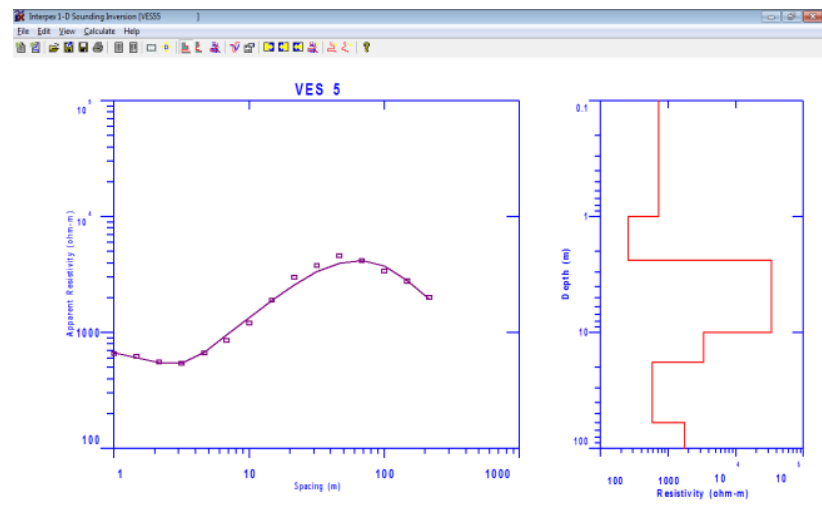

Figure 7: Geoelectric profile for VES 5

VES 1 showed six layers with the sixth layers showing indications of the presence of aquifers. The sand layers were in the sequence, topsoil, dry sand, sand, dry sand, sand and the aquiferous sand. The resistivity values were in the sequence $\rho 1<\rho 2>\rho 3<\rho 4<\rho 5>\rho 6$. The aquiferous zone has a resistivity of $509.26 \Omega \mathrm{m}$ and at a depth of $39.492 \mathrm{~m}(129.567 \mathrm{ft})$. VES 2 had six layers in the sequence topsoil, dry sand, sand, very dry sand and the aquiferous sand at the fifth layer. This layer is characterized by a very low resistivity. The trend is $\rho 1<\rho 2>\rho 3<\rho 4>\rho 5$. The depth of this aquiferous sand is at $63.808 \mathrm{~m}(209.344 \mathrm{ft})$

VES 3 also had six layers with the aquiferous sand at the sixth layer with a resistivity of $192.20 \Omega \mathrm{m}$. the depth of this aquiferous sand is at $37.588 \mathrm{~m}(123.320 \mathrm{ft})$. The trend of the resistivities for the layers are $\rho 1<\rho 2<\rho 3>\rho 4<\rho 5>\rho 6$. The soil sequence is topsoil, sand, dry sand, sand, dry sand and aquiferous sand. VES 4 has a soil sequence of topsoil, sand, sand, sand, very dry sand, dry sand and the aquiferous sand. The VES here encountered seven layers with the seventh layer being the aquiferous sand. This sand has a very low resistivity of $580 \Omega \mathrm{m}$. the depth of this layer is below the $32.413 \mathrm{~m}$ (106.342ft) sand layer. The resistivity sequence is $\rho 1<\rho 2>\rho 3>\rho 4<\rho 5>\rho 6<\rho 7$. VES 5 had five layers of topsoil, sand, very dry sand, dry sand and the aquiferous sand. The aquiferous sand with a resistivity of $575.67 \Omega \mathrm{m}$ was encountered at the depth of $59.748 \mathrm{~m} \quad(196.023 \mathrm{ft})$. the resistivity sequence is $\rho 1>\rho 2<\rho 3>\rho 4>\rho 5$

A 3D EARTH interpretation was also done for the data also and an elevation map, depth to static water table and a flow direction map was generated and it show a direction of the fringes having a higher elevation and the central area with the lower elevation.

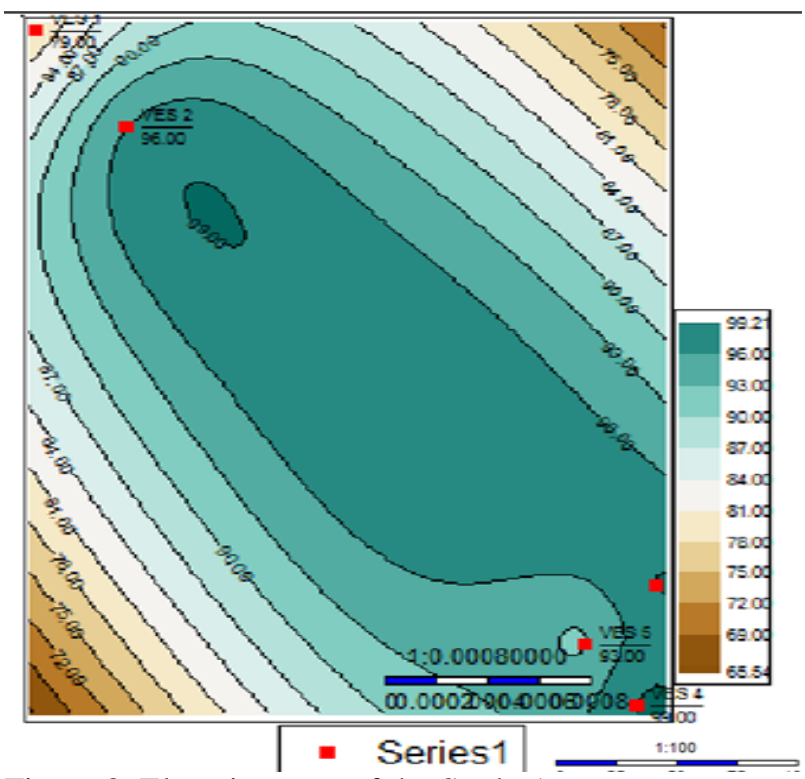

Figure 8: Elevation map of the Study Area

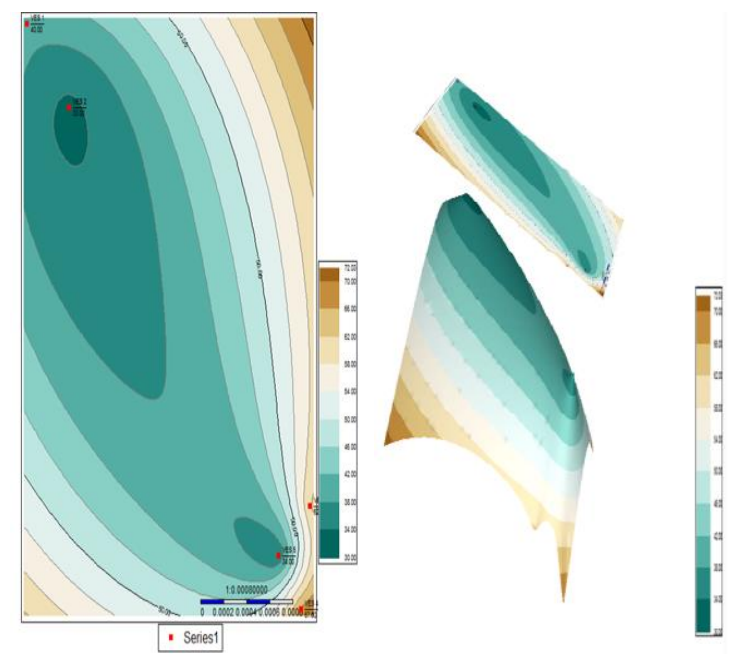

Figure 9: Depth to Static Water table.

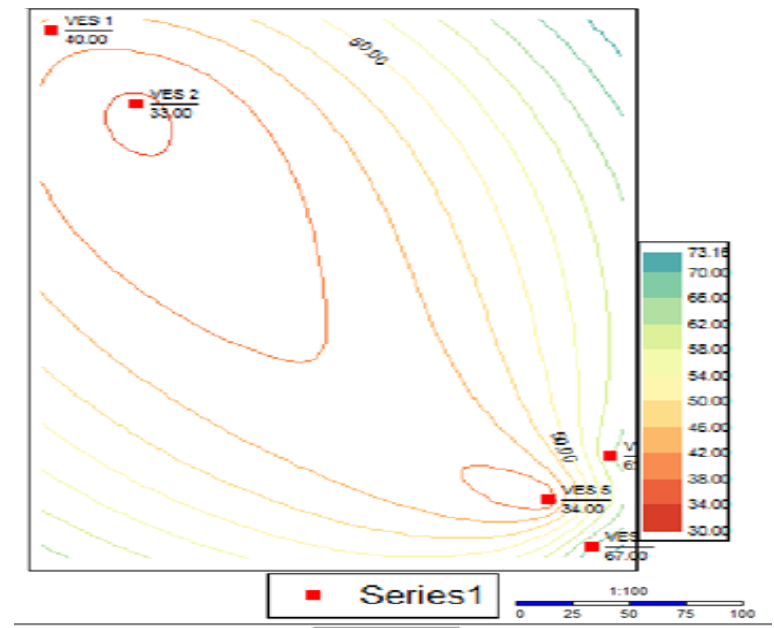

Figure 10: Groundwater Flow Direction 


\section{CONCLUSION}

For portable and adequate water to be encountered and drilled for within the area where the geophysical survey was carried out, the depths with the lowest resistivities should be drilled to and it is at these depths that water will be encountered [14] The depths 129.567ft (VES 1), 209.344ft (VES 2), 123.320ft (VES 3), 106.342 (VES 4) and 196.023 (VES 5) are the depths at which ground water could be encountered in large quantities. VES 2 and VES 5 are the points with more likelihood of much productivity and due to the depth and this can also be true for the contamination level of the groundwater, which will have less contamination.

\section{ACKNOWLEDGEMENT}

The Authors are grateful to the Department of Geology, University of Benin for providing the equipment and softwere for this work.

\section{REFERENCE}

[1] Ariyo, S.O., and Banjo, AA (2008) Application of electrical resistivity method for groundwater exploration in a sedimentary terrain: A case study of Ilara-Remo, Southwest Nigeria: Continental Journal of Earth Sciences, v. 3, p53 - 58 .

[2] Alisiobi AR and Ako BD (2012) Groundwater Investigation Using Combined Geophysical Methods. Adapted from extended abstract prepared in conjunction with poster presentation at AAPG Annual Convention and Exhibition, Long Beach, California. AAPG 2012

[3] Emenike, E.A. (2001) Geophysical exploration for groundwater in a Sedimentary Environment: A case study from Nanka over Nanka Formation in Anambra Basin, Southeastern Nigeria: Global Journal of Pure and Applied Sciences, v. 7/1, p. 1-11.

[4] Carruthers, R.M. (1985) Review of geophysical techniques for groundwater exploration in crystalline basement terrain: British Geological Survey, Regional Geophysics Research Group, Report 85/3, 30 p.

[5] Short K. and Stauble AJ. (1967) Outline of the geology of Niger Delta. Am Assoc Petroleum Geologists Bull; 51: 761-79

[6] Alayaki, F., Al-Tabbaa, A., and Ayotamuno, J., (2015). Defining Niger Delta Soils: Are They Laterites? Civil and Environmental Research www.iiste.org, Vol.7, No.5.

[7] Andre-Obayanju, O., Imarhiagbe, OJ. and Onyeobi, TUS (2017) Comparative Evaluation of Geotechnical Properties of Red Tropical Soils and Anthills from parts of Edo State for Road Construction. J. Appl. Sci. Environ. Manage. Vol. 21 (7) 1250-1255

[8] Murat R.C. 1972. Stratigraphy and Paleogeography of the cretaceous and Lower Tertiary in S. Nigeria. Proceedings of 1st Conference on African geology, 1970, Ibadan, Nigeria. Ibadan University Press. pp. 251-266.

[9] Nwajide, C.S. (2013) Geology of Nigeria's Sedimentary Basins. CSS Bookshop Ltd., Lagos, 1-565.
[10] Barker, R.D. (1980): "Application of Geophysics in Groundwater Investigation”. Water Surv. 84:489-492.

[11] Telford, W.M. Geldart, LP Sheriff, RE and Keys, DA (1990) Applied Geophysics (Second Edition: Cambridge University Press, p. 344-536.

[12] Kollert, R., (1969) Groundwater exploration by the electrical resistivity method: ABEM Geophysical memorandum, v. $3 / 69$, p. $1-8$

[13] Alile OM, Jegede SI, Ehigiator OM (2008b). Underground water exploration using electrical resistivity method in Edo State, Nigeria, Asian J. Earth Sci. 1(1): 38-42

[14] Odusanya A., and Amadi, (1990): An empirical resistivity model for predicting shallow groundwater occurrence in the basement complex. Water Resources Journal of Nigeria Association of Hydrogeologist,2 pp 78-87. 